\title{
Quotations in translation: A case study
}

\author{
Ailish Maher \\ Freelance Translator and Editor \\ amjm@telefonica.net
}

DOI: ti.105202.2013.a07

\begin{abstract}
Quotations pose specific requirements regarding attribution, scientific integrity and copyright and so place an onus on the translator to assume - at least some - responsibility for compliance with these requirements in the translated text. This article examines and systematically applies style guide criteria to a set of quotations that were sufficiently varied and numerous to constitute a useful case study. The article concludes by discussing dilemmas and suggesting tentative guiding principles.
\end{abstract}

Keywords: Citation, quotation, translation, reference, bibliography

\section{Introduction}

\subsection{Quotations: what's the problem?}

Quotations pose requirements regarding attribution, scientific integrity and copyright, often not viewed as part of the translator's task. However, the interface between languages places an onus on the translator to assume - at least some - responsibility for compliance with these requirements in the translated text. The complexity of the problem is best illustrated by fairly typical dilemmas that affect, not just the text, but also the bibliography, as adaptations to the text may also affect references (Table 1).

\begin{tabular}{|l|l|}
\hline Translation language pair & Scenarios \\
\hline FR to EN & $\begin{array}{l}\text { A French researcher reads Bertrand Russell in a French translation and } \\
\text { the text for translation contains a quote from this French version. }\end{array}$ \\
\hline DE to EN & $\begin{array}{l}\text { A German researcher reads Stephen Hawking in the English and } \\
\text { paraphrases an extract in German in the text for translation. }\end{array}$ \\
\hline ES to EN & $\begin{array}{l}\text { A Spanish researcher reads a famous Paul Klee publication in German } \\
\text { and paraphrases an extract in Spanish in the text for translation. }\end{array}$ \\
\hline IT to EN & $\begin{array}{l}\text { An Italian researcher reads a thesis by a German author and } \\
\text { paraphrases an extract in the text for translation. }\end{array}$ \\
\hline
\end{tabular}

Table 1. Some examples of quote/paraphrase dilemmas in translation

This article systematically examines a set of quotations - from two very similar texts by the same author - that proved to be an ideal case study given the number of quotations, the reputation of many of the cited authors and the diversity of languages and nationalities involved.

It should be noted that the two texts in question were research articles in the social sciences area and, although much of what is discussed here is relevant to other fields (e.g. art catalogues, history, etc.), requirements regarding quotations and their referencing may be different. 
The article is laid out as follows: Section 1.2 provides some theoretical background on intertextuality concepts from a translation perspective;

Section 2 describes sources of guidance, specifically, style guides; Section 3 provides basic details of the case study and discusses approaches to different kinds of quotations; Section 4 considers particular issues and provides summary guidelines; and Section 5 concludes the article. ${ }^{1}$

\subsection{Intertextuality: The sea of texts}

Intertextuality is simply — or simplistically — defined as 'the complex interrelationship between a text and other texts taken as basic to the creation or interpretation of the text' (Merriam-Webster, 2013). All texts draw, in some way, on previous texts. 'Bits of code, formulae, rhythmic models, fragments of social languages, etc., pass into the text and are redistributed within it, for there is always language before and around the text' (Barthes, 1981, p.39).

Intertextuality helps us identify particular texts as belonging to particular domains. This is why identifying genre and text type is an important first step in translation, as it enables us to map texts within the broad sea of texts. Acquiring expertise in particular genres, furthermore, leads us to expect - and enables us to reproduce - certain patterns of intertextuality. As just one example, in research articles based on the introduction, methods, results and discussion (IMRAD) structure, certain kinds of information belong in specific sections and we need to know when information may be misplaced.

Translation itself is a unique case of intertextuality, according to Venuti (2009, p.158), who describes three sets of intertextual relations: between the foreign text and other texts, between the foreign text and the translation, and between the translation and other texts. Originals, for instance, frequently contain implicit or explicit references to people, geographical locations and cultural artefacts (literature, films, exhibitions, conferences, etc.) that can only be successfully 'transferred' if the translator can recognise, understand and render the semantic implications of the intertextual reference.

Translators, therefore, need to be able to recognise the 'bits of code' referred to by Barthes, that is, to have sufficient literary and cultural knowledge to recognise intertextual relations and interpret them (Venuti, 2009, pp.157158). Sometimes the code is immediately identifiable; in other cases, it is less evident. From the working translator's perspective, therefore, intertextuality can be broadly categorised according to whether it is implicit or explicit (Table 2).

\begin{tabular}{|l|l|}
\hline IMPLICIT/INDIRECT & EXPLIIT/DIRECT \\
Summary & Citation \\
Paraphrase & Quotation \\
Allusion, metonymy, etc & \\
Recycling & \\
Echoing & \\
Language of the discourse community & \\
\hline
\end{tabular}

Table 2. Kinds of intertextuality

\footnotetext{
${ }^{1}$ To avoid confusion between authors of quotations and the author who commissioned the translation, I will refer to the commissioning author as the 'researcher'. 'Bibliography' will also be used in preference to 'references', to avoid any possible confusion with citation or reference in any other sense.
} 
Explicit intertextuality - citation or quotation - is a device used in scholarly or academic writing: knowledge is a collective enterprise in which scientists and academics use and build on the ideas of others, so these others need to be identified, both to give credit where credit is due and to enable information to be verified. Citation and quotation also demonstrate that a position or argument is thoroughly researched.

Citations and quotations share two common features: first, they both have a textual and a referential component, with the former acting as a signpost to the latter; and second, the fact of the intertextuality is 'marked'. The textual component for citations is typically a recycling of the original author's words or ideas and a parenthetical reference or note (the author + date or the numbering system) to indicate the source. For quotations, the textual component also consists of an indication of the source (possibly with the additional detail of a page number), but in this case, the author's own exact words are used, 'marked' as such using some typographic convention (e.g. quotation marks, block indentation or italics). The referential component (the 'signpost' to the bibliography) is the same for both citations and quotations: the abbreviated textual attribution links to a list of references or to a footnote with full bibliographical details of the works cited. The interested reader is thus provided with enough information on the source to be able to further explore or cross-check information.

Implicit and explicit intertextuality both make demands on translators. The capacity to recognise implicit intertextuality, in particular, marks translators as culturally competent, i.e. as capable of sharing the culture of the writer, of reproducing the language of the discourse community, of recognising allusions, etc. Explicit intertextuality is easier to recognise, as citations and quotations are both clearly marked using whatever typographic conventions apply. But quotation, more so than citation, squarely places translators on the frontier between the languages and cultures of the source text (ST) and target text (TT). Citation and quotation are identical in terms of needing to be referenced, but in quotation, unlike citation, the exact words of the original author must be reproduced. As the case study examples below will illustrate, the interface between languages - a source language (SL), a target language (TL) and sometimes a third or even more languages - may complicate the translator's task to an inordinate degree.

\subsection{Copyright and fair use}

Many translators consider the bibliography to be beyond their remit, especially as clients often specifically ask translators to ignore this part of their manuscript. With implicit intertextuality, there is no general requirement to indicate source (e.g. for an allusion like 'the Mad Hatter's tea party'), so there is no need to adapt the bibliography. With citations, the bibliography likewise remains unchanged, except, possibly, for minor typographical corrections (see Rodgers, 2010). With quotations, however, changes with important copyright implications may need to be made to the text and the bibliography and, depending on how they are handled, may leave the client open to an accusation of incompetence, plagiarism - a form of illicit intertextuality (see Roig, 2006) - or even breach of copyright law.

Copyright, fair use and fair dealing are topics that are extensively treated in major style guides and so will only be referred to in passing in this article. As the case study examples will illustrate, changes to quotations often affect the bibliography and so have copyright implications. It should be remembered that copyright laws differ between countries and delineating the differences between, for example, US and UK law is beyond the scope of this article. However, in regard to fair use/fair dealing, factors to be broadly 
considered include purpose (e.g. commercial or otherwise) and length/proportion in relation to the rest of the work. It should be noted that fair use/fair dealing obviates the need to request permission, but not the need to credit authors. Thus, for example, in regard to this article, just the sources are indicated for the style guide extracts reproduced here, as they are covered by fair use/fair dealing, whereas the author's permission was obtained for the examples that form the basis of the case study, given that they represent a substantial proportion of her texts.

\section{Style guides}

Several style guides (Table 3) were searched for guidance regarding quotations using, as initial search terms, 'translation', 'translator', 'quotation', 'citation' and 'foreign language' and later adding in the terms 'derivative work', 'fair use' and 'copyright', once it became clear that, from a publisher's perspective, these were inextricably and intimately linked to citation and quotation.

\begin{tabular}{|l|l|}
\hline Name and year of publication & Basic details \\
\hline Oxford Style Manual (OSM), 2003 & UK, hardcopy, general \\
\hline Chicago Manual of Style (CMOS), 2010 & USA, online, general \\
\hline Canadian Style Guide (CSG), 1997 & Canada, online, general \\
\hline Modern Language Association (MLA), 2008 & USA, hardcopy, humanities \\
\hline Modern Humanities Research Association (MHRA), 2008 & UK, hardcopy, humanities \\
\hline Interinstitutional Style Guide (IISG), 2012 & EU, online, general \\
\hline American Psychological Association Publication Manual (APA), 2001 & USA, hardcopy, social sciences \\
\hline American Medical Association Manual of Style (AMA), 2007 & USA, hardcopy, medical \\
\hline Butcher's Copy-editing, 2006 & UK, hardcopy, editing \\
\hline
\end{tabular}

Table 3. Style guides consulted

It should be noted that the major general style guides for the two most important variants of English are included. Nonetheless, the list is neither exhaustive nor objective but reflects the style guides in my possession, familiar to me and/or accessible on the Internet; furthermore, style guides were searched that, a priori, would not seem to be relevant to the task (e.g. AMA), but it was considered preferable to avoid drawing foregone conclusions. Finally, Butcher's was consulted as a comprehensive and reputable source for editors.

The guides found to provide the most exhaustive guidance were the general-language OSM and CMOS (Table 4a), with the CMOS providing the most comprehensive guidance (about twice as much information as the OSM). Interestingly, the guides that were available in more than one language version - the CSG, in French and English, and the IISG, in several languages of the EU - provided very little guidance, although this may simply reflect their institutional nature. 


\begin{tabular}{|c|c|}
\hline GUIDE & UNIT \\
\hline \multirow{7}{*}{ 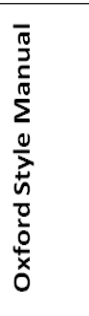 } & 8.2. Foreign language quotations \\
\hline & 13.11. Translation and transliteration \\
\hline & - 13.11.1.4. Scope of translation \\
\hline & - 13.11.1.6. Quotations \\
\hline & - 13.11.1.7. References \\
\hline & - 13.11.1.11. Bibliographies \\
\hline & 14. Copyright [UK law] and other publishing responsibilities \\
\hline \multirow{9}{*}{ 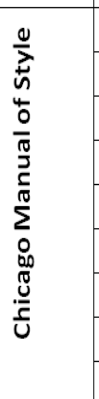 } & 4. Rights, permissions and copyright administration [US law] \\
\hline & 13.3. Giving credit and seeking permission \\
\hline & 13.4. When to paraphrase rather than quote* \\
\hline & 13.76. Crediting the translation \\
\hline & 13.79. The sin of retranslation \\
\hline & 14.69. Elements to include when citing a book \\
\hline & 14.71 Foreign bibliographic terms and abbreviations \\
\hline & 14.88. Editor or translator in addition to author \\
\hline & 14.109. Original plus published translation \\
\hline $\begin{array}{l}\dot{d} \\
\stackrel{5}{ \pm} \\
0\end{array}$ & MLA, MHRA, APA, AMA, CSG, IISG and Butcher's provide no (new) information of relevance. \\
\hline
\end{tabular}

Table 4a. Style guides: comprehensive guidance on quotations and related matters

Marked in bold in Table $4 \mathrm{a}$ are the units with information immediately relevant to quotations for which more detail is provided in Table $4 \mathrm{~b}$ (OSM) and Table 4c (CMOS).

\begin{tabular}{|c|c|}
\hline GUIDE & JNIT \\
\hline 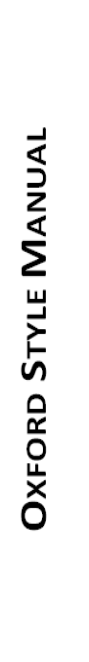 & $\begin{array}{l}\text { Chapter 13.11.1.6 Quotations } \\
\text { For works in English, use the English original if it can be traced. For works in the author's language } \\
\text { already translated into English, use published translations if reliable; if not, translate the extract } \\
\text { yourself. Works in a third language may be either in the original or translated into his/her own } \\
\text { language. Draw your editor's attention to all use of published translations in the original for advice } \\
\text { on questions of copyright. } \\
\text { Chapter 13.11.1.7 References } \\
\text { All text and footnote references to works cited in one language in the work translated and } \\
\text { another in the translation must be adjusted to the page numbers, etc. of the edition cited in the } \\
\text { translation. } \\
\text { Chapter 13.11.1.11 Bibliographies: originals and translations } \\
\text { Change to the original works in English cited in translation. Change to translations works in the } \\
\text { author's language of which good English translations exist. Works in a third language cited by the } \\
\text { author can be either in the original or in a published translation into his/her own language. If } \\
\text { there is no English version, cite the original, appending an English translation in square brackets } \\
\text {... if necessary]. [Note: Example bibliography in German and in translation to English is provided]. }\end{array}$ \\
\hline
\end{tabular}

Table 4b. OSM guidance regarding quotations

Source: Ritter, 2003. 


\begin{tabular}{|c|c|}
\hline 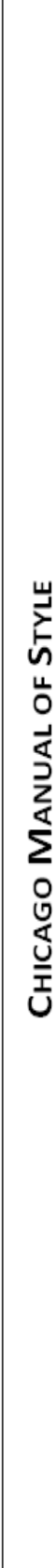 & 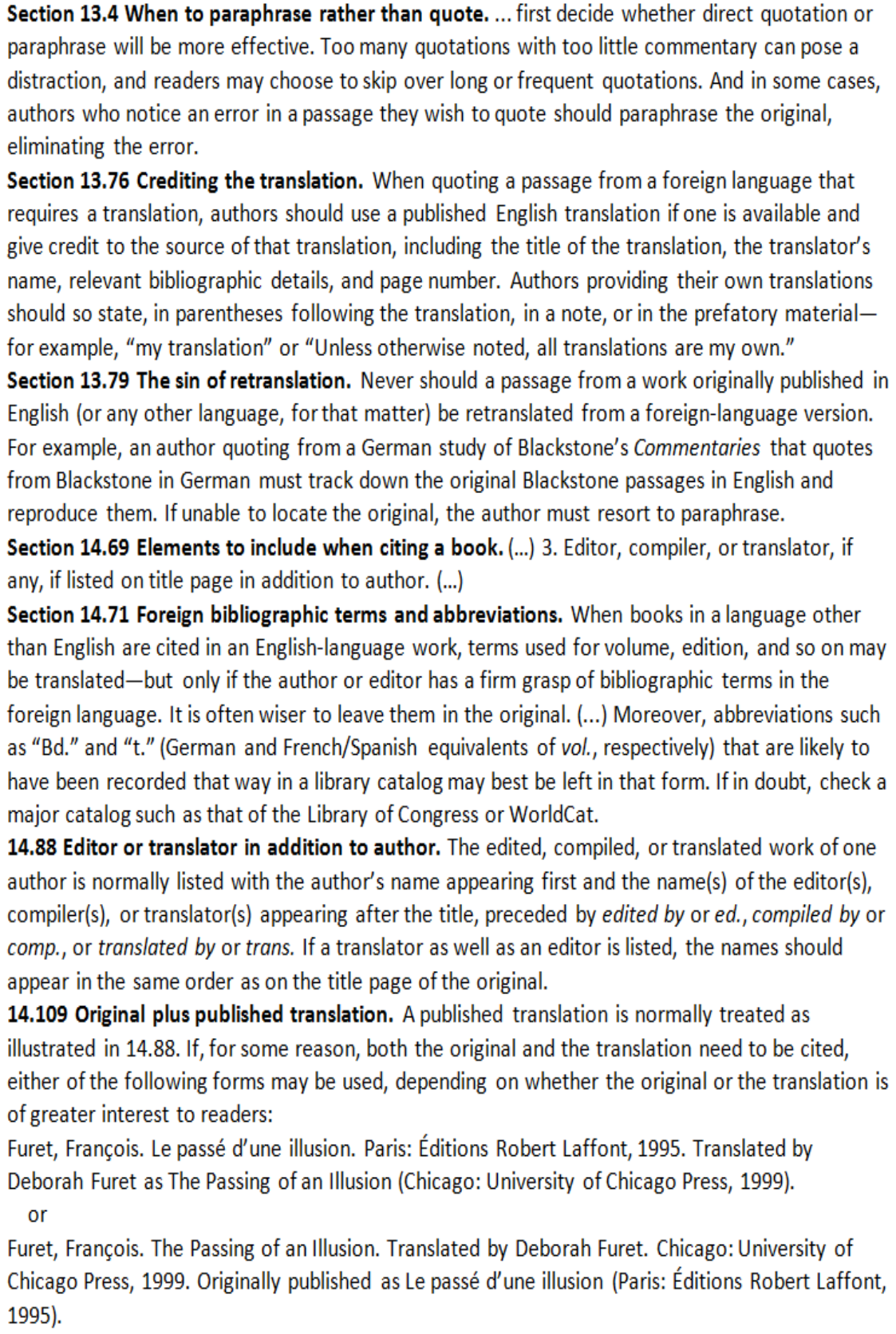 \\
\hline
\end{tabular}

Table 4c. CMOS guidance regarding quotations

Source: Chicago Press, 2010.

\section{Case study}

\subsection{Article details}

The case study refers to two similar academic articles by the same author (profiled in Table 5), written in Spanish for translation to English. They posed a particular challenge in that they contained a large number of 
quotations, many by authors with an international reputation. Furthermore, the quotations reflected several languages: the SL, the TL and the languages of authors whose first language was neither the SL nor the TL (called L3 authors below). A total of eighteen authors were cited on twenty-four occasions, almost half of them L3 authors.

\begin{tabular}{|l|l|}
\hline Genre/knowledge field & Research articles $(\times 2$ ) on educational philosophy \\
\hline Source language & Spanish \\
\hline Target language & English \\
\hline Total length & 7,058 words \\
\hline$-\quad$ Text body & 6,200 words \\
\hline$-\quad$ References & 858 words \\
\hline Authors/Quotations/Paraphrases & 18 authors - 24 quotations/paraphrases \\
\hline$-\quad$ SL author in SL & 4 authors - 6 quotations/paraphrases \\
\hline - TL author in SL/TL & 6 authors - 9 quotations/paraphrases \\
\hline- L3 author in SL/L3 & 8 authors - 9 quotations/paraphrases \\
\hline
\end{tabular}

Table 5. Profile of the case study texts

Grateful thanks to María Novo/GUNI for allowing me to use extracts from Novo 2011a and 2011b.

\subsection{Preliminary remarks regarding sources}

The following were the main online resources - somewhat more biased towards English as a target language - used to search for information regarding the quotations in this case study.

\section{Wikipedia (or another encyclopaedia)}

Any encyclopaedia is a useful source of biographical and background information (including, as appropriate, information on publications). Wikipedia, despite its credibility issues, has the particular advantage that it is available online, is usually comprehensive and is often available in several languages. Checking out encyclopaedic information regarding cited authors is useful for getting on the right track from the outset, so as not to be misled by preconceptions as to nationality or language, for example; leads may also be encountered for further searches when dead-ends are encountered.

\section{Google Books}

This database of scanned books used to make out-of-copyright books available in 'full view' and other books in 'previews' or the more restricted 'snippets'. However, I have found that the possibility of fruitfully searching Google Books has become considerably more restricted since I started this case study almost two years ago, as the database is currently in a legal limbo due to copyright issues. It continues to provide useful copyright information, however.

\section{Amazon (as an alternative to Google Books)}

Many books available in Amazon have the 'look inside' option which allows access to copyright pages and tables of content and which also permits limited keyword searches. 


\section{Index Translationum}

UNESCO's database of book translations may indicate whether a work has been translated. In particular, and provided the translation is listed, it is a good source for translator names.

\section{WorldCat}

Thousands of libraries around the world can be searched via the interface for the world's largest bibliographic database, containing useful information on different editions and the corresponding copyright details.

\section{National libraries}

National libraries, many of whose catalogues can be searched online, are another source of information, especially regarding original works in specific languages.

\section{Google (or any other search engine)}

A search engine used creatively may yield rapid results. It should be noted that not all books will be in Google Books, Index Translationum or WorldCat databases, which is why a search in a general purpose engine like Google should always be conducted.

\subsection{Case study examples}

In discussing the specific examples of the case study, it seemed preferable to simply refer to the actual languages used, namely, Spanish and English, rather than SL and TL. However, in discussions of broader relevance I will use the terms SL and TL.

The examples, which illustrate direct application or interpretation of OSM/CMOS guidance, are classified in two categories. The first category consists of 'SL authors' and 'TL authors', defined as 'authors whose language of publication coincides with the ST language' and 'authors whose language of publication coincides with the TT language', respectively. The second category consists of 'L3 authors', defined as 'authors quoted in the SL text who wrote in neither the SL nor the TL'.

The approach to each example was to apply style guide recommendations (as reflected in Table 4 above). If no explicit recommendation existed, the bibliography was adapted according to the principle of least intervention (i.e. making minimal changes to the bibliography as presented in the original article) while endeavouring to remain coherent overall (i.e. ensure a consistent approach to changes). A separate section below is devoted to discussing some of the apparent contradictions that were posed by the 'translation' of the bibliography from Spanish to one that complied with copyright and style requirements. ${ }^{2}$

\subsubsection{SL and TL authors (Tables 6a and $6 \mathrm{~b}$ )}

In the first example, the author cited was a Spanish philosopher, María Zambrano (b. 1904, d. 1991). Although preconceived notions, if wrong, incur the risk of frustrating searches, it can often be assumed that national authors who are not fairly familiar names outside their own country are not likely to be translated, so it is merely a question of carrying out some searches to confirm the hunch. In the case of Zambrano, although at least one work had

\footnotetext{
2 The question marks in the case study extracts indicate information missing at the time of delivery of the translations in spring 2011. This information was to be completed by the researcher from the copyright pages of the books she had consulted.
} 
been published in translation, it was not the work cited by this researcher. In terms of changes, the quotation was paraphrased, keeping as close as possible to the source. Page numbers were removed as there seemed to be little point in retaining them. The reference required no adaptations.

\begin{tabular}{|c|c|c|}
\hline \multirow[t]{2}{*}{ 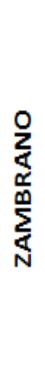 } & EXTRACT & 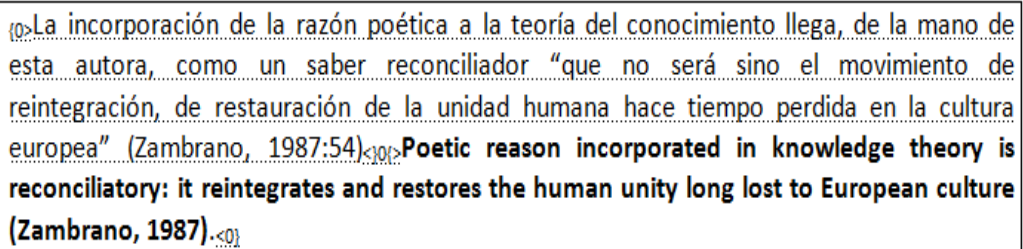 \\
\hline & REFERENCE & $\begin{array}{l}\text { \{0:ZAMBRANO, M. (1987). Pensamiento y poesía en la vida española. Madrid. } \\
\text { Endymión. } \leq 10\} \text { ZaMBRANO, M. (1987). Pensamiento y poesía en la vida española. Madrid: } \\
\text { Endymión. }<0\}\end{array}$ \\
\hline \multirow[b]{2}{*}{ 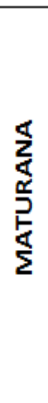 } & EXTRACT & $\begin{array}{l}\{0, \text { Hoy se acepta, como afirma Maturana (1989), que "todo lo que se ha dicho lo ha dicho } \\
\text { un observador". } \leqslant 10\} \text { Today it is accepted, as pointed out by Maturana (1987:65), that } \\
\text { "everything is said by an observer." }<0\}\end{array}$ \\
\hline & REFERENCE & 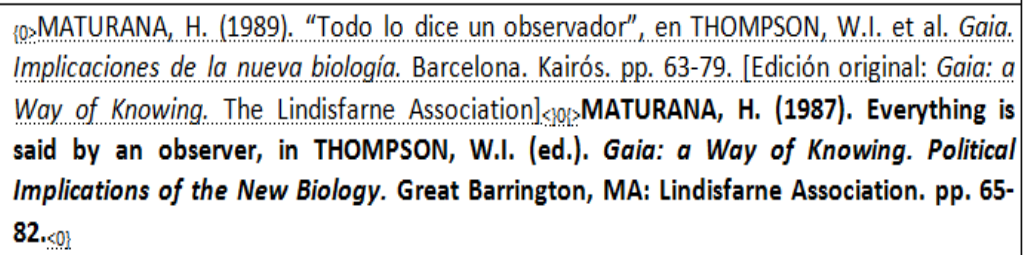 \\
\hline
\end{tabular}

Table 6a: In-text and bibliographical adaptations for SL authors

The second example, referring to Humberto Maturana (b. 1928), a Chilean biologist and epistemologist, posed slightly more of a challenge, especially as this (presumed) Spanish speaker appeared to have been published in English first. The information provided in the bibliography (referring to a collection of conference papers) guided a search in Google Books. Although it was not possible to search the book in English, it was possible to retrieve the translation of the quote, which happened to be a chapter title. The page number was found by means of Google searches for other works that cited this article. In the text, the quotation in Spanish was substituted by the one in English, the year was changed to that of the English version and page numbers were added. In the bibliography, publication details were adapted according to the copyright information for the edition found in Google Books (article, book title and page numbers). It should be noted that Thompson is the editor of both language versions, and also that the English version predates the Spanish version, so translator details are not necessary. Were we dealing with a quotation by, say, Ortega y Gasset, e.g. the famous 'Yo soy yo y mi circunstancia', rendered as 'I am myself and my circumstance' (Meditations on Quixote, 1961, translated by Evelyn Rugg and Diego Marina), then the bibliography entry would likewise contain the details of the translated work in place of the original Spanish work and would include the names of the translators. 


\begin{tabular}{|c|c|c|}
\hline \multirow[t]{2}{*}{ 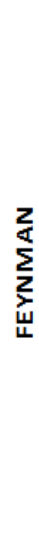 } & EXTRACT & $\begin{array}{l}\text { 10. En este sentido se pronuncia Feymann (2000) cuando afirma que podemos tener } \\
\text { respuestas aproximadas y creencias posibles, con diferentes grados de certeza, } \\
\text { pero "no estamos absolutamente seguros de nada", de forma que, cuando se } \\
\text { plantea un enunciado, la cuestión no es si es cierto o falso, sino más bien qué } \\
\text { probabilidad tiene de ser cierto o falso. } \leq 10 \text {, Feynman (1999:24) said that we could } \\
\text { have "approximate answers and possible beliefs and different degrees of } \\
\text { certainty about different things", but we could not be "absolutely sure of } \\
\text { anything". Hence, the question is not whether any statement is true or false, but } \\
\text { rather how likely it is to be true or false. }<0\}\end{array}$ \\
\hline & REFERENCE & 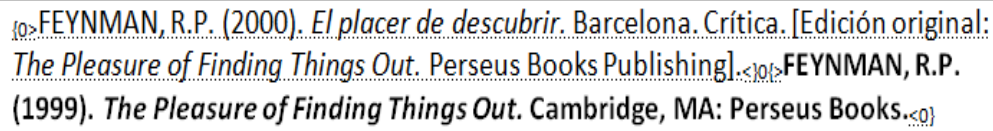 \\
\hline \multirow[t]{2}{*}{$\frac{\stackrel{r}{w}}{\frac{m}{w}}$} & EXTRACT & $\begin{array}{l}\text { 10. Este vínculo es fundamental desde lo que se conoce como "teoría de la } \\
\text { recepción". "El espectador, el lector, el oyente, se hallan implicados } \\
\text { dinámicamente en la realización de la obra de arte. Sus respuestas y sus } \\
\text { interpretaciones son esencialespara su significado" (Steiner, 2001:72). } 10 \text {. This link } \\
\text { reflects what is known as reception theory: "the viewer, reader, listener is } \\
\text { dynamically implicated in the realisation of the work of art. His response and } \\
\text { interpretations are essential to its signification" (Steiner, 2001:64).<0\} }\end{array}$ \\
\hline & REFERENCE & $\begin{array}{l}\text { \{0.STEINER, G. (2001). Gramáticas de la creación. Madrid. Siruela.[Edición original: } \\
\text { Grammars of Creation. Gifford Lectures for 1990] } \\
\text { of Creation. STEINER, G. (2001). Grammars } \\
\text { offord Lectures. New Haven: Yale University Press.<0\} }\end{array}$ \\
\hline
\end{tabular}

Table 6b: In-text and bibliographical adaptations for TL authors

As mentioned above, SL authors who may not have an international reputation are not likely to be translated. The reverse is true of TL authors: if they are translated to the SL, then it is usually because they have acquired an international reputation, at least in their field. The first example in this category is US Nobel Prizewinner, Richard Feynman (b. 1918, d. 1988). Several editions of the book referred to were available in Google Books but were not searchable. A guesswork search using the keywords 'approximate answers' located the citation and page number in a 1999 edition. Although the researcher did not explicitly quote Feynman in the first part of her sentence, given Feynman's reputation and also to compensate for 'lost' quotes elsewhere, it was decided to cite his exact words. The year and page numbers of the parenthetical reference were modified and the bibliographical details were adapted to reflect those from the copyright page of the edition quoted from.

The second example refers to French-born George Steiner (b. 1929), a literary critic, essayist, philosopher, novelist, translator and educator, whose family emigrated to the USA when he was eleven years old. Guessed keywords ('reader', 'listener', 'work of art') and reference details located the original quote in a searchable edition in Google Books. The parenthetical reference was adapted to reflect the page number for this edition, published in the same year as the translation, and the bibliographical entry reflected the details taken from the copyright page for this same edition. 


\subsubsection{L3 authors (Table 7)}

In regard to Jürgen Habermas (b. 1929), a German sociologist and philosopher, the publication referred to has been translated into English. However, the fact that a searchable edition could not be located meant that the bibliographical entry was left as in the ST, i.e. in German. The translator's task is straightforward: to translate the researcher's paraphrase based on her reading of the L3 original. The translation was not very literal as it was guided by research: several books paraphrase or cite Habermas using more or less the words used in my translation.

In the second example, the author cites from a translation into Spanish of a work by Edgar Morin (b. 1921), a French philosopher and sociologist. The bibliography provides details of both the Spanish translation and the French original. There is a certain dissonance in having a dual bibliographical entry that represents two languages, neither of which is the TL (in this case, English). But despite a 'reasonable' investment in time and effort, no English translation could be 'married up' with the French original with $100 \%$ certainty. Hence, paraphrasing was the only possible option (guided by principles such as least intervention, risk reduction and pragmatism) and page numbers were removed. Such paraphrases need to be as literal as possible or thoroughly researched, as with the Habermas example above - given the number of languages and interpretations that intervene. As for the dual bibliographical entry, applying the principle of least intervention,

bibliographical details were left as in the researcher's text. The missing detail is the translator's name, which can be searched for on the Internet or, preferably, completed by the researcher from the copyright page of the edition she consulted.

\begin{tabular}{|c|c|c|}
\hline \multirow{2}{*}{ 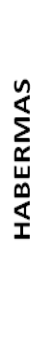 } & EXTRACT & 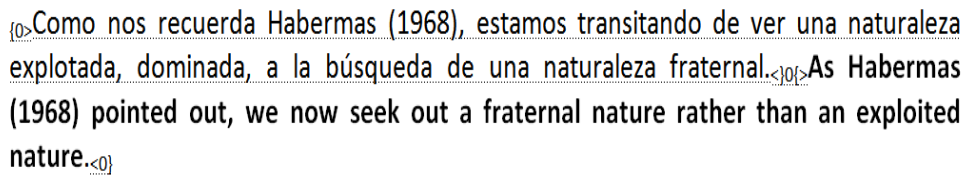 \\
\hline & REFERENCE & $\begin{array}{l}\text { [0.HABERMAS, J. (1968). Technik und Wissenschaft als "Ideologie". Frankfurt am Main. } \\
\text { Suhrkamp Verlag.<jo\} HABERMAS, J. (1968). Technik und Wissenschaft als } \\
\text { "Ideologie". Frankfurt am Main: Suhrkamp Verlag.<0\} }\end{array}$ \\
\hline \multirow{2}{*}{$\begin{array}{l}\frac{2}{\alpha} \\
\stackrel{0}{0} \\
\Sigma\end{array}$} & ACT & $\begin{array}{l}\text { [0.En efecto, la complejidad nos invita a tener en cuenta que "la mayor certidumbre } \\
\text { que nos ha dado el siglo XX es de la imposibilidad de eliminar ciertas incertidumbres, } \\
\text { no sólo en la acción sino también en el conocimiento" (Morin, 2003:72). }<j 0 \text { Indeed, } \\
\text { complexity invites us to take account of the fact that the greatest certainty of the } \\
\text { twentieth century is the impossibility of eliminating uncertainty, not only in actions } \\
\text { but also in knowledge (Morin, 2003). }\end{array}$ \\
\hline & REFERENCE & 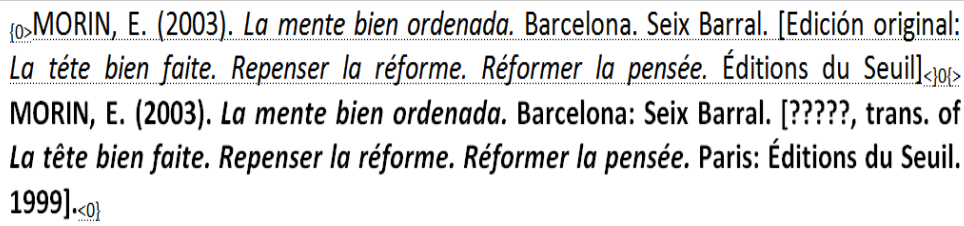 \\
\hline
\end{tabular}




\begin{tabular}{|c|c|c|}
\hline \multirow{2}{*}{ 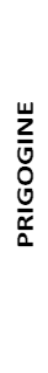 } & EXTRACT & $\begin{array}{l}\text { \{0 } 3 . . . \text { nos asomamos a una ciencia que combina determinismo con indeterminismo, una } \\
\text { ciencia que, en palabras de Prigogine (1997:109), expresa en sus leyes "lo que es posible y } \\
\text { no lo que es cierto". } \leq 00 \text { This new vision is of a science that combines determinism and } \\
\text { indeterminism, a science whose laws express, as pointed out by Prigogine (1997), what } \\
\text { is possible, not what is true. } \leq 0\}\end{array}$ \\
\hline & REFERENCE & $\begin{array}{l}\text { \{0>PRIGOGINE, I. (1997). Las leyes del caos. Barcelona. Crítica. [Edición original: Le leggi del } \\
\text { caos. Bari (Italia), Laterza].<jo\}> PRIGOGINE, I. (1997). Las leyes del caos. Barcelona: } \\
\text { Crítica. [?????, trans. of Le leggi del caos. Bari (Italy): Laterza. 1994] } \text {. }<0\}\end{array}$ \\
\hline \multirow[t]{2}{*}{$\begin{array}{l}\frac{0}{u} \\
\frac{0}{0} \\
0 \\
0\end{array}$} & EXTRACT & $\begin{array}{l}\{0>Y \text { así es como estamos viajando, en el terreno del conocimiento, a través de un proceso } \\
\text { que ha sido descrito por Popper (1965) con una bella metáfora: de los relojes a las nubes. } \\
\text { Es decir, de lo mecánico, previsible, a lo inaprensible e incierto. } \leq 50 \text {. } \text { And this is how, in the } \\
\text { field of knowledge, we move from clocks to clouds, to use the beautiful metaphor } \\
\text { coined by Popper ( } 1965 \text {, cited in Prigogine, 1997), that is, from what is mechanical and } \\
\text { predictable to what is elusive and uncertain. } \leq 0\}\end{array}$ \\
\hline & REFERENCE & $\begin{array}{l}\text { \{0>POPPER, K.R. (1965). Of clouds and clocks. [Citado por Prigogine, I. (1997-a). Las leyes del } \\
\text { caos. Barcelona. Crítica].<jo\}>PRIGOGINE, I. (1997). Las leyes del caos. Barcelona: Crítica. } \\
\text { [?????, trans. of Le leggi del caos. Bari (Italy): Laterza. 1994] }<0 \text { \} }\end{array}$ \\
\hline \multirow{2}{*}{ 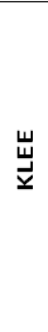 } & EXTRACT & 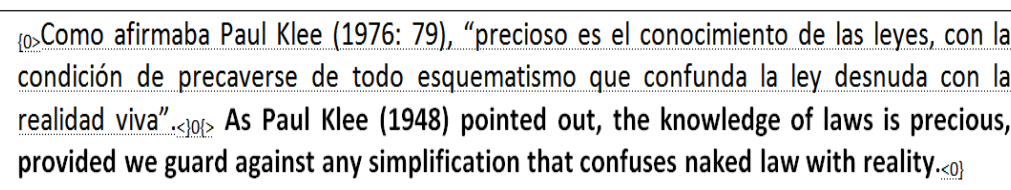 \\
\hline & REFERENCE & 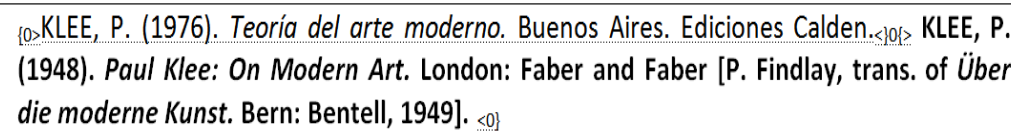 \\
\hline \multirow{2}{*}{ 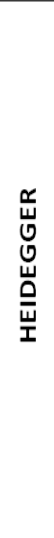 } & EXTRACT & 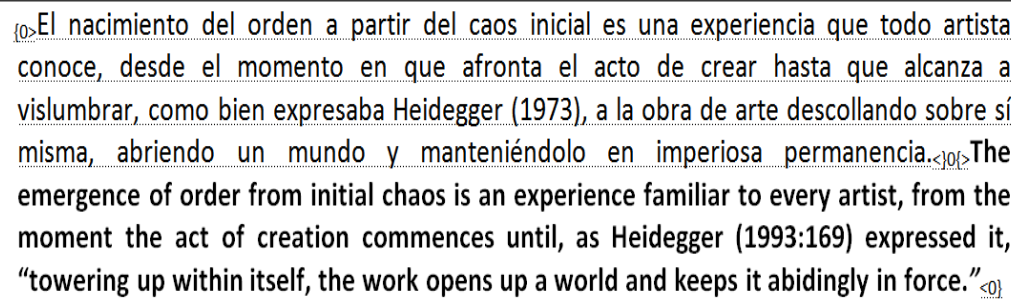 \\
\hline & REFERENCE & 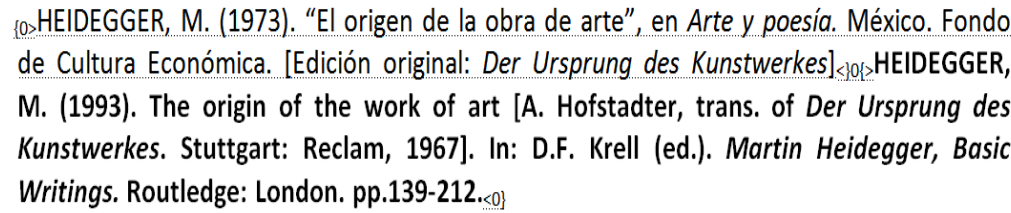 \\
\hline
\end{tabular}

Table 7. In-text and bibliographical adaptations for L3 authors

Many difficulties arose with the quotation by Prigogine (b. 1917, d. 2003), compounded by an initial preconception - based on the bibliography details and even the surname - that the author was Italian (he was, in fact, a Russianborn naturalised Belgian physical chemist and Nobel Laureate). Lengthy and circular searches eventually led to contrasting data in different library catalogues (see Appendix): the French national library indicated that the original was Italian, whereas the German catalogue referred to a translation from French. It was eventually deduced that the original publication was probably the conference paper in Italian. On this basis, the text was paraphrased - also in view of the fact that the quotation was not, in fact, linguistically or conceptually complex ('what is possible, not what is true') and the page number removed. Decisions regarding the bibliographical entry 
were very similar to those for Morin. As with Morin, the translator's name is a missing detail.

Austrian-born Karl Popper (b. 1902, d. 1994), regarded as one of the greatest philosophers of science, was a professor at the London School of Economics. Because he lived most of his life in England, Popper technically belongs in the TL author category, but the confusion arises with the secondary citation - Popper (1965) - via, as revealed by the bibliography entry, the problematic Prigogine publication described above. However, going by the principle that references should, whenever possible, indicate what the researcher has read, the parenthetical citation needs to indicate that the Popper metaphor was encountered in Prigogine and the references need to indicate that the author has read Prigogine, not Popper. Strictly speaking, this example is not directly relevant to the topic of this article, but is included because it raises the question of exactly what is meant by 'secondary' sources (discussed further below).

Paul Klee (b. 1879, d. 1940) was a Swiss-born German-speaking artist. The work cited above has been translated to English, but keyword searches in Google failed to retrieve the quotation in English, there was no preview or snippet view of the English version in Google Books and, although Amazon allowed a 'look inside', this was extremely limited and retrieved nothing for keyword searches. A pragmatic decision was made to simply paraphrase the quote, remove the page number and replace the biographical entry for the Spanish version with the English version. This has to be considered a provisional solution: for a person of the stature of Klee and given that the researcher quoted his exact words, it would be preferable to make further efforts to locate the quote in English.

For Martin Heidegger (b. 1889, d. 1976), an influential German philosopher, there were very many citations of this exact phrase in Google, so it would also seem preferable to cite this author in a published translation to English. The book was listed in Google Books but was not searchable. The quotation was located along with the page number via the 'look inside' option offered by Amazon, and the necessary details for the edition were taken from the copyright page.

\section{Discussion}

The above examples (and others from the same articles not included here in the interest of brevity) raised doubts and inspired reflection regarding the following: the bibliography and how it should be structured after translation; paraphrasing and the implications thereof; and other issues related to time, the author, etc.

\subsection{The bibliography}

The quotations and corresponding bibliographical entries above reflect OSM and CMOS recommendations. Where guidance was absent, the principle of least intervention (i.e. leaving bibliographical entries as untouched as possible) was applied. ${ }^{3}$ Below I consider some of the doubts that arose in many revisits to the bibliography that ultimately led to the configuration of a proposed 'model' bibliography.

\footnotetext{
${ }^{3}$ Tables $6 \mathrm{a}, 6 \mathrm{~b}$ and 7 represent the bibliography as delivered with the completed translation in spring 2011.
} 


\subsubsection{Should/can a bibliography reflect what the author has read?}

A bibliography must provide full details of the sources used to document an article. In a number of the bibliographical entries above, some of the adaptations to the bibliography would tend to propagate the 'fiction't that the researcher read works in English when, in fact, she read them in translation; hence, the bibliography in translation would apparently fail to comply with the above-mentioned requirement. However, we need to remember that this kind of fiction is nothing new in the translation domain: ignoring the fact that Clark Gable or Jean-Paul Belmondo are not, in fact, native speakers of Catalan, Irish, Arabic, etc., underpins the film dubbing industry. So, although a bibliography in the monolingual world is required to reflect what the author has read, in translation it is not possible to apply this rule to the letter.

\subsubsection{Should/can a work read in translation not be considered a secondary source?}

The case study has an example of Popper cited as a secondary source: the researcher had cited him as 'interpreted' by another author. Works in translation - sometimes (tellingly) referred to as 'derivative works' - are also 'interpretations' and any paraphrasing we do as translators potentially creates a Chinese whispers effect. ${ }^{5}$ This effect is exaggerated when different languages and humans intervene: e.g. in the example above, Morin was translated from French to Spanish, then from Spanish to English, and so three people - two translators and the researcher - intervened between Morin and his reader in English. The citing of secondary sources 'is generally to be discouraged' (CMOS): authors are supposed to read (or at least check) primary sources. However, in translation, the 'primary' source may be in a language the researcher does not know, so the rule of consulting primary sources cannot realistically be applied in the translation domain. Translators, nevertheless, need to be alert as to the possible existence of an original.

To a degree, then, we have to accept the fiction that a researcher wrote and read in the TL and acknowledge that a researcher cannot possibly be expected to read primary works in languages he/she does not know. Style guides merely tell us to use a published translation for quotations and to list this same edition in the bibliography (OSM; CMOS). Yet this simplistic onesize-fits-all criterion fails to reflect some of the more subtle undertones of how citation is affected by translation.

In the light of the above doubts I experimentally reviewed the case study examples to explore different options for configuring the bibliography (Table 8). Three issues need to be remembered: (1) if we quote the exact words of an author, for copyright reasons we must list the corresponding publication in the bibliography; (2) if we paraphrase, the bibliography is unaffected; and (3) any changes made to the bibliography must be coherent overall, i.e. the same principles should be applied to all the changes.

Regarding the SL and TL authors, whether to include the translated or original work, as the case may be, is theoretically optional. However, it

\footnotetext{
${ }^{4}$ I use the notion of 'fiction' in a broad sense to reflect that we may overlook the fact that actors in dubbed films and authors in translated literatures may not belong to our own cultural context.

${ }^{5}$ Further underlining the 'secondary' or 'derivative' nature of translations is the fact that one of the authors studied here, Morin, was reported to rate La mente bien ordenada poorly (Miralles, 2008). To cite Miralles (my translation): 'La mente bien ordenada, Seix Barral, Barcelona, 2002 (a poor translation to Spanish, according to Edgar Morin. Another translation has been published in Argentina as La cabeza bien puesta. Nueva Visión, Buenos Aires, 1999).'
} 
would seem logical to always include the original as well, as it indicates that a work was read in translation. As for order, if paraphrasing, it seems logical to put the translation first; if quoting, the style guides indicate that the work quoted from goes first. However, it should be noted that, for quotes from TL authors, the argument for including what the author actually read makes little sense (Feynman in translation to Spanish, for instance).

\begin{tabular}{|l|l|l|l|}
\hline \multicolumn{2}{|l|}{ ST IN SPANISH } & TT IN ENGLISH & COMMENTS \\
\hline $\begin{array}{l}\text { SL author } \\
\begin{array}{l}\text { NOT } \\
\text { translated } \\
\text { to English }\end{array}\end{array}$ & $\begin{array}{l}\text { Zambrano } \\
\text { dijo: "que no } \\
\text { será sino..." }\end{array}$ & $\begin{array}{l}\text { PP: Zambrano said that it ... } \\
\text { Then BIB: Pensamiento y poesía en la vida } \\
\text { española. }\end{array}$ & $\begin{array}{l}\text { Bibliography remains } \\
\text { the same. }\end{array}$ \\
\hline $\begin{array}{l}\text { SL author } \\
\text { translated } \\
\text { to English }\end{array}$ & $\begin{array}{l}\text { Ortega y } \\
\text { Gasset: } \\
\text { "Yo soyyo ..." }\end{array}$ & $\begin{array}{l}\text { If PP: Ortega y Gasset said that he was .... } \\
\text { Then BIB: Meditaciones del Quijote }\end{array}$ & $\begin{array}{l}\text { If QT: Ortega y Gasset: "I am I ...." } \\
\text { Then BIB: Meditations on Quixote + } \\
\text { the same. }\end{array}$ \\
$\begin{array}{l}\text { Mediaciones del Quijote } \\
\begin{array}{l}\text { TL author } \\
\text { NOT } \\
\text { translated } \\
\text { to Spanish }\end{array}\end{array}$ & $\begin{array}{l}\text { Brown dijo } \\
\text { quela } \\
\text { realidad ... }\end{array}$ & $\begin{array}{l}\text { PP: Brown said that the reality } \\
\text { Then BIB: Treatise on reality }\end{array}$ & $\begin{array}{l}\text { Order of works is } \\
\text { switched. Visibility of } \\
\text { SL is retained. } \\
\text { Researcher's reading is } \\
\text { reflected }\end{array}$ \\
\hline
\end{tabular}

\begin{tabular}{|c|c|c|c|}
\hline \multirow[t]{2}{*}{$\begin{array}{l}\text { TL author } \\
\text { translated } \\
\text { to Spanish }\end{array}$} & \multirow[t]{2}{*}{$\begin{array}{l}\text { Feynman: "No } \\
\text { estamos..." }\end{array}$} & $\begin{array}{l}\text { If PP: Feynman said that we were not ... } \\
\text { Then BIB: El placer de descubrir + } \\
\text { The pleasure of finding things out }\end{array}$ & $\begin{array}{l}\text { Order of works is } \\
\text { switched. Visibility of } \\
\text { SL is retained. } \\
\text { Researcher's reading is } \\
\text { reflected. }\end{array}$ \\
\hline & & $\begin{array}{l}\text { If QT: Feynman: "We're not...." } \\
\text { Then BIB: The pleasure of finding things out }\end{array}$ & $\begin{array}{l}\text { Visibility of } S L \text { is lost. } \\
\text { Researcher's reading is } \\
\text { not reflected. }\left(^{*}\right)\end{array}$ \\
\hline $\begin{array}{l}\text { L3 author } \\
\text { NOT } \\
\text { translated } \\
\text { to } \\
\text { English }\end{array}$ & $\begin{array}{l}\text { Morin: "La } \\
\text { mayor } \\
\text { certidumbre } \\
\text {.." }\end{array}$ & $\begin{array}{l}\text { PP: Morin said that the greatest uncertainty } \\
\text {... } \\
\text { Then BIB: La mente bien ordenada + } \\
\text { La tête bien faite }\end{array}$ & $\begin{array}{l}\text { Bibliography remains } \\
\text { the same. }\end{array}$ \\
\hline \multirow{2}{*}{$\begin{array}{l}\text { L3 author } \\
\text { translated } \\
\text { to } \\
\text { English }\end{array}$} & \multirow{2}{*}{$\begin{array}{l}\text { Heidegger:"... } \\
\text { Descollando } \\
\text { sobresí } \\
\text { misma..." }\end{array}$} & $\begin{array}{l}\text { If PP: Heidegger said .... towering up within .... } \\
\text { Then BIB: El origen de la obra de arte + } \\
\text { Der Ursprung des Kunstwerkes }\end{array}$ & $\begin{array}{l}\text { Bibliography remains } \\
\text { the same. }\end{array}$ \\
\hline & & $\begin{array}{l}\text { If QT: Heidegger: "towering up within ..." } \\
\text { Then BIB: The origin of the work of art + } \\
\text { Der Ursprung des Kunstwerkes }\end{array}$ & $\begin{array}{l}\text { Visibility of } S L \text { is lost. } \\
\text { Researcher's reading is } \\
\text { not reflected. }\left(^{*}\right)\end{array}$ \\
\hline
\end{tabular}




\begin{tabular}{|c|c|c|c|}
\hline \multirow[t]{2}{*}{$\begin{array}{l}\text { TL author } \\
\text { translated } \\
\text { to Spanish }\end{array}$} & \multirow[t]{2}{*}{$\begin{array}{l}\text { Feynman: "No } \\
\text { estamos ..." }\end{array}$} & $\begin{array}{l}\text { If PP: Feynman said that we were not ... } \\
\text { Then BIB: El placer de descubrir + } \\
\text { The pleasure of finding things out }\end{array}$ & $\begin{array}{l}\text { Order of works is } \\
\text { switched. Visibility of } \\
\text { SL is retained. } \\
\text { Researcher's reading is } \\
\text { reflected. }\end{array}$ \\
\hline & & $\begin{array}{l}\text { If QT: Feynman: "We're not...." } \\
\text { Then BIB: The pleasure of finding things out }\end{array}$ & $\begin{array}{l}\text { Visibility of } S L \text { is lost. } \\
\text { Researcher's reading is } \\
\text { not reflected. }\left(^{*}\right)\end{array}$ \\
\hline $\begin{array}{l}\text { L3 author } \\
\text { NOT } \\
\text { translated } \\
\text { to } \\
\text { English }\end{array}$ & $\begin{array}{l}\text { Morin: "La } \\
\text { mayor } \\
\text { certidumbre } \\
\ldots \text {... }\end{array}$ & $\begin{array}{l}\text { PP: Morin said that the greatest uncertainty } \\
\text {... } \\
\text { Then BIB: La mente bien ordenada + } \\
\text { La tête bien faite }\end{array}$ & $\begin{array}{l}\text { Bibliography remains } \\
\text { the same. }\end{array}$ \\
\hline \multirow{2}{*}{$\begin{array}{l}\text { L3 author } \\
\text { translated } \\
\text { to } \\
\text { English }\end{array}$} & \multirow{2}{*}{$\begin{array}{l}\text { Heidegger:"... } \\
\text { Descollando } \\
\text { sobre sí } \\
\text { misma ..." }\end{array}$} & $\begin{array}{l}\text { If PP: Heidegger said .... towering up within .... } \\
\text { Then BIB: El origen de la obra de arte + } \\
\text { Der Ursprung des Kunstwerkes }\end{array}$ & $\begin{array}{l}\text { Bibliography remains } \\
\text { the same. }\end{array}$ \\
\hline & & $\begin{array}{l}\text { If QT: Heidegger: "towering up within ..." } \\
\text { Then BIB: The origin of the work of art + } \\
\text { Der Ursprung des Kunstwerkes }\end{array}$ & $\begin{array}{l}\text { Visibility of } S L \text { is lost. } \\
\text { Researcher's reading is } \\
\text { not reflected. }\left(^{*}\right)\end{array}$ \\
\hline
\end{tabular}

Table 8. Impact of quotations and paraphrase on the TL bibliography

Notes. PP refers to paraphrase, QT to quotation and BIB to bibliography. In the Comments column the asterisk in brackets $(*)$ indicates that there has been a 'loss' in translation.

For this particular case study, to comply with copyright and style guide recommendations, the best solution in terms of achieving overall coherence in the bibliography for all three kinds of authors (SL, TL and L3) was as follows:

(1) Always include the original - but note that it is not logical to always include translations (e.g. Feynman).

(2) If an author is quoted, list the work quoted from and, if this is a translated work, also include the original work (e.g. Heidegger).

(3) If an author is paraphrased, list what the researcher read and include the original work if a translation (e.g. Morin).

For the L3 authors, the work may or may not be available in translation. When no translation is available, as with Morin, the only option (other than quoting the original French) is to paraphrase the Spanish. The problem is deciding what language versions to include in the bibliography. The doubts are similar when a translation is available (as with Heidegger) - except that now we have three language versions as candidates for the bibliography. So, should we include the Spanish translation, the English translation (if available), the French (Morin) or German (Heidegger) original and, if so, in which order? If we apply the principles above, we should include the original for both Morin and Heidegger; we should also include the translation to Spanish for paraphrased material (Morin); and we should also include the work quoted for quoted material (Heidegger).

Having considered all the options for including or excluding titles, it seemed that two issues overrode all other considerations (once copyright and style guide recommendations were respected): to reflect original works, and, if possible, to reflect what the researcher read. Table 9 depicts how the case 
study text and bibliography would look after applying the 'rules' worked out above.

TEXT

With his famous statement, "I am myself and my circumstances", José Ortega y Gasset (2000:45) (...)

Poetic reason (...) reintegrates and restores the human unity long lost to European culture (Zambrano, 1987). (...) Today it is accepted, as pointed out by Maturana (1987:65), that "everything is said by an observer." (...) Feynman (1999:24) said that we could have "approximate answers and possible beliefs and different degrees of certainty about different things", but we could not be "absolutely sure of anything". Hence, the question is not whether any statement is true or false, but rather how likely it is to be true or false. (...)This link reflects what is known as reception theory: "the viewer, reader, listener is dynamically implicated in the realisation of the work of art. His response and interpretations are essential to its signification" (Steiner, 2001:64). (...) As Habermas (1968) pointed out, we now seek a fraternal nature rather than an exploited nature. (...) Indeed, complexity invites us to take account of the fact that the greatest certainty of the twentieth century is the impossibility of eliminating uncertainty, not only in actions but also in knowledge (Morin, 1999). (...) This new vision is of a science that combines determinism and indeterminism, a science whose laws express, as pointed out by Prigogine (1994), what is possible, not what is true. (...) we move from clocks to clouds, to use the beautiful metaphor coined by Popper (1965, cited in Prigogine, 1994), that is, from what is mechanical and predictable to what is elusive and uncertain. (...) As Paul Klee (1948) pointed out, the knowledge of laws is precious, provided we guard against any simplification that confuses naked law with reality. (...) from the moment the act of creation commences until, as Heidegger (1993:169) expressed it, "towering up within itself, the work opens up a world and keeps it abidingly in force."

\section{REFERENCES}

FEYNMAN, R.P. (1999). The Pleasure of Finding Things Out. Cambridge, MA: Perseus Books. HABERMAS, J. (1968). Technik und Wissenschaft als "Ideologie". Frankfurt am Main: Suhrkamp Verlag.

HEIDEGGER, M. (1993). The origin of the work of art [A. Hofstadter, trans. of Der Ursprung des Kunstwerkes. Stuttgart: Reclam, 1967]. In: D.F. Krell (ed.). Martin Heidegger, Basic Writings. Routledge: London. pp.139-212.

KLEE, P. (1976). Teoría del arte moderno. Buenos Aires. Ediciones Calden. [H. Acevedo, trans. of Über die moderne Kunst. Bern: Bentell, 1949].

MATURANA, H. (1987). Everything is said by an observer. In: THOMPSON, W.I. (ed.). Gaia: a Way of Knowing. Political Implications of the New Biology. Great Barrington, MA: Lindisfarne Association. pp. 65-82.

MORIN, E. (2003). La mente bien ordenada. Barcelona: Seix Barral. [M.J. Buxó-Dulce Montesinos, trans. of La tête bien faite. Repenser la réforme. Réformer la pensée. Paris: Éditions du Seuil. 1999]. ORTEGA Y GASSET, J. (2000). Meditations on Quixote. Champaign: University of Illinois Press. [E. Rugg and D. Marin, trans. of Meditaciones del Quijote. Madrid: Revista de Occidente en Alianza Editorial, 1981].

PRIGOGINE, I. (1997). Las leyes del caos. Barcelona: Crítica. [J. Vivanco, trans. of Le leggi del caos. Bari (Italy): Laterza. 1994].

STEINER, G. (2001). Grammars of Creation. Gifford Lectures. New Haven: Yale University Press. ZAMBRANO, M. (1987). Pensamiento y poesía en la vida española. Madrid: Endymión.

Table 9. The translated text and the 'model' references and bibliography 
Notes. To facilitate reading, the in-text parenthetical references are underlined. Ortega y Gasset, not in the articles used for this case study, is 'artificially' included here to illustrate what to do with an SL quotation. In the interest of having a complete 'model' bibliography, missing translator details (for Klee, Morin and Prigogine) were located via online searches.

There is a small loss in this 'translation' of the bibliography: we imply that the researcher read an eminent author from another culture in English Feynman - when in fact she read him in translation, and we imply that she read an L3 author like Heidegger in translation to English rather than (what was really the case) to Spanish.

\subsection{Paraphrasing}

Returning to the text, let us consider the important issue of paraphrasing and the implications. In translation, quotes may or may not be converted into paraphrases and vice versa, depending on decisions based on a number of factors. These decisions should not, however, be made lightly and overall coherence in dealing with a bibliography is primordial. From the discussion in the previous section (4.1), we can draw conclusions as follows:

(1) Paraphrasing in the TT is, broadly speaking, an acceptable solution for material that was paraphrased in the ST.

(2) Paraphrasing in the TT is an option for dealing with quotations in the ST for which a published translation does not exist, cannot be located or is unsuitable.

(3) Paraphrasing leaves the bibliography in translation unchanged but should only be considered as a last resort (the 'easy', but not necessarily the 'right' option).

Two other points can be made regarding paraphrasing. First, authors with an international reputation (Feynman, for instance) are likely to have been translated, so every effort should be made to locate the work - and his words - in translation (even if afterwards we decide not to use them). This is even more so the case when we have a sentence or phrase like Heidegger's above ('towering up within itself etc.'): the wording is so very distinctive that paraphrase would be extremely difficult (compare with Prigogine's very straightforward 'what is possible, not what is true').

Second, we need to be aware of levels of interpretation when we paraphrase. As pointed out earlier regarding Morin, several languages and 'interpretations' intervene between the writer and reader. In an ideal world we would locate (and translate from) the original or would enlist the help of the researcher or a colleague. Failing this, we would need to be as literal as possible in order to avoid any possible Chinese whispers effect. Naturally, whenever possible we should try to confirm our 'interpretation' through research (as with the Habermas example); background research and crosschecks are especially crucial in 'guiding' the choice of words to use when paraphrasing complex language and concepts (as with the Heidegger example).

Bearing other factors in mind, paraphrase may be the most (only) pragmatic solution as an alternative to lengthy, convoluted searching, most especially when L3 authors are involved (e.g. the publication sought may be very old or the third language may not be known to the translator). In this case the decision to paraphrase may be dictated by principles such as least intervention, risk reduction and pragmatism. 


\subsection{Time, researcher collaboration and other issues}

The translation of articles with bibliographies as described in this case study is time consuming, and difficulties are potentially many and varied. The decision to call off the search for an original is most often pragmatic, based on: (1) the time consumed, especially when searches seem to be leading nowhere; and (2) the risk implied by the translator's intervention in a text that is ultimately not his/her own. In dealing with references, the translator does not have access to the information that the researcher has drawn on (the context of the quotation and the copyright pages of the works read) and so, ultimately, relies on the author's willingness to cooperate and, perhaps, to even agree to make changes to the text in order to avoid copyright problems.

As an example of a complex search effort, the Prigogine work cited above as Los leyes del caos/Le leggi del caos required a great deal of time merely to determine the original language of the work (never mind whether it existed in translation to English) and, even then, the information seemed to be contradictory. In my subsequent research for this article (but not for the original translation delivered in spring 2011), I unearthed what was possibly an English translation, details as follows: Order Out of Chaos: Man's New Dialogue with Nature, written by Ilya Prigogine and Isabelle Stengers and published in 1985. I say possibly, for the following reasons: the title is rather different; Stengers is included as an author; there is a subtitle that does not exist in the Italian original or Spanish translation; and the years confuse (the possible English 'translation' dates from 1985, whereas the citation is for a translation from 1994). This merely illustrates how marrying up translations and originals is not always straightforward. We can speculate endlessly and search again and again, but at some point we may have to acknowledge that our information is incomplete and must resort to a pragmatic solution unless we are collaborating very closely with the author and are being rewarded accordingly.

It is clear from the above that the main difficulties arise with L3 authors. Thus, the greater the status of the author, the greater the obligation to locate the translation (since, even if we decide not to use it, we need to locate it to make that decision); the older the work the more likely we will have difficulties, unless it is so old that it is available from Project Gutenberg; much depends on what possibilities we have for accessing the publication in Google Books or Amazon (or a local library); and, finally, our own knowledge of the L3 will affect our searches.

It is evident, given the difficulties and the time required, that the translator may need to get the researcher on board at an early stage for copyright reasons. The text and the bibliography should be assessed before translation, particularly for quotations by L3 authors and for any text that might raise questions as to fair use/fair dealing and the need to obtain permissions.

Other issues that arose in dealing with the case study examples are commented briefly as follows:

(1) Even if a published translation is available, it is entirely legitimate for the translator to provide their own, alternative, translation, which should, nonetheless, be indicated as such. If a quotation appears not to fit seamlessly with an argument, it can be paraphrased, reduced or parcelled into snippets.

(2) Very famous authors, if quoted in the ST, should probably be quoted (not paraphrased) in the TT, unless there are valid reasons for not doing so. For example, although it was possible to locate a translation of a work by Paul Klee, it proved impossible to locate the exact quotation. 
(3) Whether to remove any reference to pages, even for paraphrased text, is a matter of the style being applied. Some style guides require page numbers to be provided even for paraphrased text; other style guides require page numbers to be provided only for quoted matter. Translators may decide to exclude page numbers when they convert a quote into a paraphrase.

(4) Changes made to a bibliographic entry should reflect the actual edition quoted from. If at all possible, details should be obtained from the copyright page (in Google Books or Amazon, from an online national or international catalogue, from a book stocked in a library or directly from the author).

(5) If several editions of a translation are available, an edition published before the translation should preferably be cited.

(6) Even if no copyright issues arise, the bibliography may need minimum changes (terms used for volume, edition, city names and so on).

(7) The major style guides are unanimous: when referring to a translated work, the only mandatory detail is the name of the translator - yet this is often omitted. Index Translationum or creative searching in Google may yield translator names but it is preferable for the author to confirm this detail from the copyright page of the work consulted.

(8) Dealing with quotations is not an exact science, so an overall perspective on a text and the references is necessary when making decisions. The most important thing is, ultimately, to be entirely coherent in the decisions made, within the text and within the bibliography.

\section{Conclusions}

This article has dissected a translation process that involved decisions regarding numerous quotations and paraphrases of authors in a source text in Spanish translated to English. The main conclusion is that different texts are likely to pose different problems and so should be dealt with on a case-bycase basis. Texts with bibliographical entries referring to third languages are likely to pose greater difficulty, essentially because the third language impinges on the dual-language interface between the ST and the TT.

In terms of basic guidelines, the fundamental rule is that copyright and style guide recommendations must be respected. Another guideline is that changes made to the bibliography should be internally coherent (if the details of a translation are provided for one author, they should be provided for other authors in similar circumstances). It is also recommended to include the original works, as this is obligatory for publications quoted from but is also a way of (1) placing on record that works were read in translation and (2) maintaining the visibility of other languages. Finally, when the exact words of an author are quoted, the bibliography must include the corresponding work. However, when an author is paraphrased, it seems more logical to include the work the author read.

On a more practical level, quotations are potentially time consuming, and the potential copyright implications would indicate the need for dialogue with the researcher. Both these facts represent an additional time investment by the translator that is not generally anticipated or recognised. From the translator's perspective, the remuneration for a translation with a handful or more of quotations may not be commensurate with the substantial extra work invested in dealing with these quotations and making the corresponding bibliographical adaptations, especially in situations where, due to the copyright implications, translators simply cannot overlook the bibliography (even if so instructed). 
In the course of this research, I experimented with different bibliography configurations, finding that two extremes were possible: the visibility of the researcher and her language and culture could have been retained or could have been lost. The latter bibliography would imply that the researcher read in English (already in translation we imply that she wrote in English) and would also largely relegate Spanish, the SL, to the level of a third language. In the course of this research, I arrived to the conclusion that, ultimately over and above respect for intertextual links and compliance with copyright and style guides - it was also important to retain the visibility of the researcher and her language and culture and so minimise the perpetration of 'ethnocentric violence' (Venuti, 1995, pp.20-24) on the text by translation.

\section{Acknowledgements}

Thanks to Susan diGiacomo for her review of the manuscript and for drawing my attention to Venuti (1995) and his discussion of 'ethnocentric violence', to APTIC and MET members (Barcelona) - especially Anne Murray and Ann-Marie Bohan - for input and feedback, and to the anonymous reviewers for their valuable suggestions and comments. 


\section{References}

American Medical Association (2007), AMA Manual of Style (10th ed.), New York: Oxford University Press.

American Psychological Association (2001), Publication Manual of the American Psychological Association (5th ed.), Washington DC: American Psychological Association.

Barthes, R. (1981). Theory of the text (trans. MacLeod). In: R. Young (Ed.), Untying the Text: A Poststructuralist Reader, London: Routledge and Kegan Paul, pp. 31-47.

Butcher J., Drake C. and Leach M. (2006), Butcher's Copy-editing. The Cambridge Handbook for Editors, Copy-editors and Proofreaders (4th ed.), Cambridge: Cambridge University Press.

Chicago Press (2010). Chicago Manual of Style (16th ed.). Retrieved October 23, 2012, from http://www.chicagomanualofstyle.org/tools citationguide.html.

European Union (2011), Interinstitutional Style Guide [English]. Retrieved July 23, 2013, from http://publications.europa.eu/code/en/en000100.htm.

Merriam-Webster (2013), Intertextuality [definition]. Retrieved July 23, 2013, from http://www.merriam-webster.com/dictionary/intertextuality.

Miralles, R. (2008). Un pensador de la complejidad. e4blog. Retrieved October 23, 2012, from http://edicion4.com.ar/e4blog/?tag=pensamiento-complejo.

Modern Humanities Research Association (2008), MHRA Style Guide. A Handbook for Authors, Editors and Writers of Theses (2nd ed.), Bath: Modern Humanities Research Association.

Modern Language Association (2008), MLA Style Manual and Guide to Scholarly Publishing (3rd ed.), New York: Modern Language Association of America.

Novo, M. (2011a). The dialogue between science and art in the construction of knowledge: a proposal for higher education. In: Global University Network for Innovation (GUNI), Higher Education in the World 4. Higher Education's Commitment to Sustainability: From Understanding to Action. Basingstoke: Palgrave-Macmillan, pp.259-261.

Novo, M. (2011b). Higher education, modernity and a new paradigm. In: Global University Network for Innovation (GUNI), Higher Education in the World 4. Higher Education's Commitment to Sustainability: From Understanding to Action. Basingstoke: Palgrave-Macmillan, pp.242-246.

Public Works and Government Services Canada (1997), The Canadian Style. A Guide to Writing and Editing (2nd ed.). Retrieved July 23, 2013, from http://www.btb.termiumplus.gc.ca/tpv2guides/guides/tcdnstyl/indexeng.html?lang=eng\&lettr=\&page=../introduction .

Ritter, R. (2003). Oxford Style Manual. Oxford: Oxford University Press.

Rodgers, J. (2010). Whose citations are they? The Write Stuff, 19(1), 47-50. Retrieved February 23, 2013, from http://www.emwa.org/JournalPDFs/J_V19_I1.pdf

Roig, M. (2006). Avoiding plagiarism, self-plagiarism, and other questionable writing practices: A guide to ethical writing. Retrieved February 23, 2013, from http://www.cse.msu.edu/ alexliu/plagiarism.pdf 
Venuti, L. (1995). The Translator's Invisibility. A History of Translation. Oxford: Routledge.

Venuti, L. (2009). Translation, intertextuality, interpretation. Romance Studies, 27(3), pp.157-173. 


\section{Appendix \\ Contradictory data regarding Prigogine from different library catalogues}

\begin{tabular}{|c|c|}
\hline $\begin{array}{l}\text { Index } \\
\text { Translationum }\end{array}$ & $\begin{array}{l}\text { Prigogine, llya: Les lois du chaos [French], (Textes de deux conférences données en } 1992 \text { à } \\
\text { I'Université de Milan) [French] / Paris: Flammarion [France], 1994. } 125 \text { p. ill., couv. ill. en coul. } \\
\text { [Italian] [English]. }\end{array}$ \\
\hline $\begin{array}{l}\text { Bibliothèque } \\
\text { Nationale de } \\
\text { France }\end{array}$ & $\begin{array}{l}\text { Type: texte imprimé, monographie } \\
\text { Auteur(s): Prigogine, llya (1917-2003) } \\
\text { Titre(s): Les lois du chaos [Texte imprimé] / Ilya Prigogine } \\
\text { Traduction de: Le leggi del caos } \\
\text { Publication: Paris: Flammarion, } 1994 \\
\text { Impression: 53-Mayenne : Impr. Floch } \\
\text { Description matérielle : } 125 \text { p. : ill., couv. ill. en coul. ; } 23 \mathrm{~cm} \\
\text { Collection: Nouvelle bibliothèque scientifique } \\
\text { Lien à la collection: Nouvelle bibliothèque scientifique. }\end{array}$ \\
\hline $\begin{array}{l}\text { Deutsche } \\
\text { National- } \\
\text { bibliothek }\end{array}$ & $\begin{array}{l}\text { Link zu diesem Datensatz: http://d-nb.info/944437680 } \\
\text { Titel: Die Gesetze des Chaos / Ilya Prigogine. Aus dem Franz. von Friedrich Griese } \\
\text { Person(en): Prigogine, llya } \\
\text { Verleger: Frankfurt/Main; New York: Campus-Verl. Paris: Ed. de la Fondation Maison des Sciences } \\
\text { de l'Homme } \\
\text { Erscheinungsjahr: } 1995 \\
\text { Umfang/Format: } 115 \mathrm{~S} . ; 21 \mathrm{~cm} \\
\text { Gesamttitel [Edition Pandora/Europäische Vorlesungen] Edition Pandora: Europäische } \\
\text { Vorlesungen; } 6 \\
\text { Einheitssachtitel: Les lois du chaos <dt.> } \\
\text { ISBN/Einband/Preis: } 3-593-35327-X \text { (Campus-Verl.) kart. : DM 28.00, sfr 28.00, S } 219.00 \\
\text { Schlagwörter Chaostheorie; Einführung } \\
\text { Sachgruppe(n): } 29 \text { Physik, Astronomie } \\
\text { Links: Inhaltsverzeichnis }\end{array}$ \\
\hline
\end{tabular}

Note. The BNF says 'Traduction de: Le leggi del caos', whereas the DNB says 'Aus dem Franz.' ('from the French') after 'Titel: Die Gesetze des Chaos /Ilya Prigogine', then later refers to 'Les lois du chaos' as the uniform title ('Einheitssachtitel'). Interestingly, a uniform title is used to identify an item if it has appeared under varying titles. 